Linguista: Jurnal IImiah Bahasa, Sastra, dan Pembelajarannya

Vol.4, No.1, Juni 2020, hal 1 - 8

ISSN (print): 2579-8944; ISSN (online): 2579-9037

Avaliable online at: http://e-journal.unipma.ac.id/index.php/linguista

\title{
Peningkatan Ketrampilan Menulis Cerpen Berbasis Pengalaman Pribadi Siswa SMA menggunakan Model Sinektis
}

\author{
Yuli Asmara Budi Nurani \\ 1)SMAN 1 GEGER, Jl. Raya Uteran No. 634, Sumberejo, Geger, Kabupaten Madiun, \\ Indonesia \\ e-mail: yuliasmara25@gmail.com
}

\begin{abstract}
Abstrak
Penelitian ini bertujuan untuk meningkatkan kemampuan siswa dalam menulis cerita pendek yang didasarkan pada pengalaman pribadi. Penelitian ini dilakukan di SMAN 1 Geger kabupaten pada siswa kelas XI IPA 2 dengan menerapkan model sinektis. Penelitian tindakan kelas ini dilakukan dalam bentuk siklus pembelajaran yang dilakukan dalam dua siklus. Terdapat peningkatan skor rata-rata kemampuan menulis cerpen siswa dari pra siklus hingga selesainya siklus sebesar 17,35. Secara garis besar model sineksis mampu meningkatkan kemampuan menulis cerpen bagi siswa.
\end{abstract}

Kata kunci: Keterampilan Menulis Cerpen; Model Sinektis

\section{Improving Short Story Writing Skills Based on the Personal Experience of High School Students using the Synectical Model}

\begin{abstract}
This study aims to improve students' ability to write short stories based on personal experience. This research was conducted at SMAN 1 Geger district on students of class XI IPA 2 by applying the synectical model. This classroom action research was conducted in the form of a learning cycle which was carried out in two cycles. There is an increase in the average score of students' short story writing skills from precycle to completion of the cycle of 17.35 . Broadly speaking, the synexis model can improve the ability to write short stories for students.
\end{abstract}

Keywords: Short Story Writing Skills; Synectical Model

\section{Pendahuluan}

Menulis cerita pendek (cerpen) tidak menjadi sesuatu yang mudah bagi seorang pemula (Setyaningsih, 2010), khususnya bagi siswa di sekolah menegah atas (SMA). Keterampilan menulis tidak dapat didapatkan dengan sendirinya, melainkan membutuhkan sebuah latihan teratur serta pola pendidikan yang terprorgam. Siswa diajak untuk berpikir kreatif dalam pembelejaran menulis di sekolah, siswa perlu diberi kesempatan seluasluasnya untuk mengeksplorasi dan elaborasi serta menuangkan apa yang ada dipikirannya dalam bentuk cerpen (Mubaroq \& Subyantoro, 2017). Aktivitas menulis merupakan keterampilan yang semua orang bisa melakukannya, yang berebda adalah tingkat kualitas hasil tulisannya (Sholeh \& Afriani, 2016).

Kreativitas siswa dibutuhkan dalam rangka menuangkan ide/gagasan kedalam cerpen yang ia tulis (Hilal, 2013), namun faktanya masih ada siswa yang bahkan belum dapat menuangkan ide gagasan seca tertulis. Menurut 
(Sholeh \& Afriani, 2016) siswa harus belajar dan mengasah keterampilan menulis dalam bentuk praktik langsung, tidak hanya pada toeri tentang kepenulisan saja. Akan tetapi kenyataan dilapangan dalam pembelajaran menunjukkan pembelajaran menulis kurang menjadi perhatikan dan cenderung untuk diabaikan. Maka mendampingi siswa dalam kegiatan penulisan cerpen sangat dibutuhkan untuk mendapatkan hasil yang maksimal.

Pembelajaran menulis cerpen supaya dapat efektif diperlukan strategi pembelajaran yang dapat memberikan peluang kepada siswa supaya dapat lebih aktif, kreatif, dan inovatif (Wahyuni, 2015). Salah satu model pembelajaran yang ditawarkan untuk meningkatkan kemampuan menulis cerpen yakni model sinektis. Dimana inti dari model sinektis menurut (Joyce \& Weil, 1986) merupakan aktivitas metafota yang meliputi analogi personal, analogi langsung dan konflik yang dipadatkan. Model sinektik merupakan model pembelajaran yang memfasilitasi peserta didik untuk berpikir kreatif dan menggunakan prosedur-prosedur sinektik untuk mengembangkan kelompok-kelompok kreativitas (Mubaroq \& Subyantoro, 2017).

Peneitian (Saragih, 2016) model sinektis efektif meningkatkan kemampuan menulis novel bagi mahasiswa. Sedangkan (Setyaningsih, 2010) model Sinektis dapat meningkatkan keterampilan menulis cerpen bagi mahasiswa, ini menjadi salah satu landasan apakah hal sama juga dapat berlaku untuk jenjang dibawahnya. Penelitian (Mubaroq \& Subyantoro, 2017) menunjukkan bahwa model sinektis lebih efektif dibandingkan dengan model kreatif produktif untuk menuliskan cerpen siswa dalam tinjauan tipe informasi. Penelitian (Hilal, 2013) menunjukkan metode sinektis lebih efektif jika dibandingkan dengan PBI untuk menuliskan cerpen berdasarkan kisah orang lain. Menurut penelitian yang dilakukan (Amintaningsih, 2011) model sinektis mampu meningtkan keterampilan menulis cerpen berbasis KUIK. Penelitian yang dilakukan oleh (Amintaningsih, 2011; Hilal, 2013) berbeda dengan penelitian ini walaupun sama-sama menerapkan model sinektis, penelitian ini menerapkan model sinektis untuk meningkatkan kemampuan menulis cerpen yang hanya didasarkan oleh pengalaman langsung dari penulis dalam hal ini siswa. Penelitian (Hilal, 2013) cerpennya didasarkan pada cerita orang lain sedang penelitian yang dilakukan oleh (Amintaningsih, 2011) penulisannya berbasis KUIK.

\section{Metode Penelitian}

Pengambilan data pada penelitian ini merujuk pada model penelitian tindakan kelas, model penelitian tindakan kelas lazim dilakukan dalam penelitian bidang pendidikan bahas Indonesia seperti yang dilakukan oleh (Kadarusman \& Cahyono, 2018; Kusrianti \& Suharto, 2019; Sayekti, 2019). Penelitian tindakan kelas ini direncakan dalam sebuah pelaksanaan siklus pembelajaran. Tiap-tiap siklus terdiri atas tahapan (1) perencanaan, (2) tindakan, (3) observasi, dan (4) refleksi. 


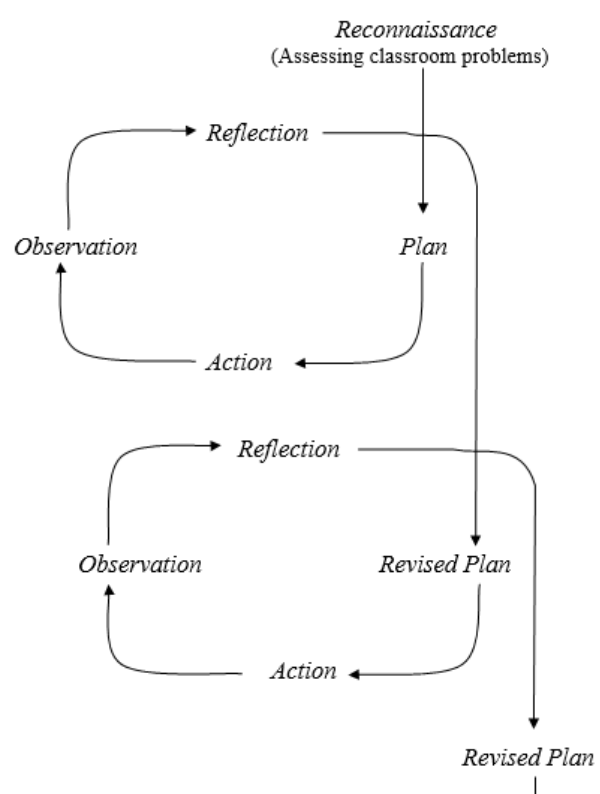

Gambar 1. Sikuls Penelitian Tindakan Kelas

(Kemmis \& McTaggart, 1988; Latief, 2009)

Penelitian ini dilaksanakan di SMAN 1 Geger pada siswa kelas XI IPA2 dengan jumlah 31 orang siswa. Penelitian dilakukan pada tahun akademik 2018/2019. Dalam penelitian ini peneliti dibantu oleh sejawat (guru bahsa Indonesia) dan mahasiswa ppl sebagai observer dalam pelaksanaan tindakan. Pengumpulan data dilakukan dengan teknik tes untuk mengetahui keterampilan menulis cerpen, tes dilakukan dengan siswa praktek langsung dalam pembuatan cerpen. Sedangkan observasi dilakukan untuk mengetahui pelaksanaan pembelajaran respon siswa dalam mengikuti pembelarajan dengan model sinektik.

\section{Hasil dan Pembahasan}

\section{Pra Siklus}

Kondisi awal keterampilan siswa dalam menyusun cerpen tercermin seperti pada tabel 1.

Tabel 1. Kemampuan menulis cerpen siswa sebelum dilaksanakan tindakan

\begin{tabular}{llcc}
\hline No & Aspek Penilaian & Skor Rata-rata & Kategori \\
\hline 1 & Tema & 55,67 & Kurang \\
\hline 2 & Isi (Kelengkapan dan keterpaduan) & 55,9 & Kurang \\
\hline 3 & Kemenarikan & 58,8 & Kurang \\
\hline 4 & Penggunaan Bahasa & 57,2 & Kurang \\
\hline & Rata-rata & 56,89 & Kurang \\
\hline
\end{tabular}

Beradasarkan tabel 1, terkait dengan baseline data awal kemampuan menulis cerpen siswa kelas XI IPA 2 rata-rata adalah 56,89. Aspek tema dan isi cerpen yang dihasilkan memiliki skor yang rendah. Data awal ini dijadikan rujukan untuk menyusun perencanaan pada siklus 1. Maka diputuskan pada siklus 1 menerapkan model pembelajaran sineksis dalam tujuan meningkatkan keterampilan menulis cerpen siswa, hal ini merujuk 
pada hasil penelitian yang pernah dilakukan oleh (Amintaningsih, 2011; Hilal, 2013).

\section{Tindakan Siklus 1}

Data pada pra siklus untuk aspek tema dan isi dari naskah cerpen yang dihasilkan menjadi titik focus utama untuk mengalami peningkatan disamping dengan dua unsur penilaian yang lain. Siklus 1 diawali dengan guru merefresh pengetahuan siswa dengan kepenulisan cerpen. Selanjutnya siswa diminta untuk menuangkan ide kreativitas yang telah dielaborasi dalam penulisan cerpen sebagai tagihan utama pada siklus 1 . Adapun hasil penilaian kemampuan menulis cerpen bagi siswa pada siklus 1 seperti pada tabel 2 .

Tabel 2. Kemampuan menulis cerpen siswa pada siklus 1.

\begin{tabular}{llcc}
\hline No & Aspek Penilaian & Skor Rata-rata & Kategori \\
\hline 1 & Tema & 66,8 & Cukup \\
\hline 2 & Isi (Kelengkapan dan keterpaduan) & 65,53 & Cukup \\
\hline 3 & Kemenarikan & 68,86 & Cukup \\
\hline 4 & Penggunaan Bahasa & 67,8 & Cukup \\
\hline & Rata-rata & 67,25 & Cukup \\
\hline
\end{tabular}

Tabel 2 merupakan potret dari hasil pelaksanaan pembelajaran pada siklus 1 dimana rata-rata hasil kemampuan menulis cerpen siswa berada pada kategori cukup yakni sebesar 67.25. Dimana terdapat 7 orang siswa sudah berhasil melampui kriteria ketuntasan minimal (KKM) kemampuan menulis cerpen pada pelaksanaan tindakan di siklus 1 . Sebayak $23,3 \%$ siswa dinyatakan lulus KKM dalam pembelajaran siklus 1 ini.

Jika kita perhatikan dari aspek- aspen yang paling rendah masih pada isi dan tema. Hasil pengamatan dalam kegiatan pembelajaran siswa dalam pembelajaran masih kurang aktif, ini dilihat dari poses bertanya dan menjawab pertanyaan dari guru yang dirasa masih belum maksimal dilakukan oleh siswa. Beberapa siswa menyampaikan bahwa dalam kondisi menulis cerpen ruang kelas dirasa membatasi imajinasi mereka. Beberapa proses sinektik tertentu dikembangkan dari beberapa asumsi tentang psikologi kreativitas (the psychology of creativity) (Rostika, 2016). Asumsi pertama, dengan membawa proses kreatif menuju kesadaran dan dengan mengembangkan bantuan-bantuan eksplisit menuju kreativitas, kita dapat secara langsung meningkatkan kapaitas kreatif secara individu maupun kelompok. Hal ini dijadikan masukkan bagi peneliti dalam rangka penyusunan rencana pelaksanaan siklus ke 2 dengan model sinektik dengan memanfaat ruang terbuka disekitar sekolah. Mengamati hasil ketrampilan menulis cerpen dari pra siklus dan hasil siklus 1 mengalami peningkatan. Akan tetapi peningaktan belum mencapai level yang diharapkan dala penelitian ini karena masih sebagian besar siswa belum 
dapat mencapai ketuntasan minimal. Ketuntasan minimal keterampilan menulis cerpen yang telah ditetapkan minilam 70 . Dengan peningkatan hanya sebesar 10,36 dirasa masih jauh dari apa yang diharapkan.

Berdasarkan hasil refleksi pada siklus ke 2 guru tidak perlu terlalu banyak memberikan teori terkait dengan penulisan cerpen. Fokus kepada contoh-contoh cerpen yang baik, menugaskan kepada siswa untuk membaca sebanyak-banyak novel sebelum pelaksanaan siklus ke dua dilaksanakan. Setiing ruang pembelajaran pada siklus 2 juga dibedakan dengan siklus 1 , pada siklus ke 2 saat mulai tahapan menulis cerpen siswa diberikan kesempatan seluas-luasnya untuk memilih tempat yang menurut mereka nyaman, sehingga ide-ide dan kreativitas yang dimiliki oleh siswa dapat terserap dengan baik dalam cerpen. Menurut (Amintaningsih, 2011) imajinasi dalam menulis cerpen dapat muncul pada diri penulis disebabkan pengalaman lahir dan batin penulis serta interaksinya sebagai makhluk sosial di lingkungan masyarakat.

Hasil pada siklus 1 memberikan gambaran bahwa siklus 2 perlu dilaksanakan, hal ini dilaksanakan mayoritas siswa belum memenuhi KKM. Rata-rata pencapaian keterampilan menulis cerpen yang didapatkan siswa kelas XI IPA 2 masih dalam kategori cukup. Dimana untuk mendapatkan hasil yang lebih maksimal siswa diminta untuk mendalami perenungan pengalaman pribadinya. Serta setting pembelejaran diluar kelas menjadi opsi untuk dilaksanakan pada siklus 2.

\section{Tindakan Siklus 2}

Pelaskanaan tindakan siklus 2 secara sintaks sama dengan pembelajaran pada siklus 1, akan tetapi pada siklus 2 memberikan porsi pengalaman menulis cerpen lebih banyak jika dibandingkan dengan penyampaian materi dari guru. Pembelajaran di siklus 2 dimulai di perpustakaan sekolah untuk penguatan materi dan debriefing selanjutnya siswa diberikan kesempatan seluas-luasnya untuk memilih tempat dimana mereka dapat nyaman untuk menuangkan ide, gagasan dan kreativitasnya dalam penulisan cerpen.

Hasil penilaian kinerja siswa dalam pembuatan cepen dengan model sinektis pada tindakan siklus ke 2 seperti pada Tabel 3.

Tabel 3. Kemampuan menulis cerpen siswa pada siklus 2.

\begin{tabular}{llcc}
\hline No & Aspek Penilaian & Skor Rata-rata & Kategori \\
\hline 1 & Tema & 73.63 & Baik \\
\hline 2 & Isi (Kelengkapan dan keterpaduan) & 73,8 & Baik \\
\hline 3 & Kemenarikan & 73,9 & Baik \\
\hline 4 & Penggunaan Bahasa & 75,63 & Baik \\
\hline & Rata-rata & 74,24 & Baik \\
\hline
\end{tabular}

Tabel 3 menunjukkan bahwa rata-rata keterampilan siswa dalam menulis cerpen masuk kategori baik, dengan skor rata-rata 74,24. Dari 31 
siswa kelas XI IPA 2 terdapat dua orang anak yang masuk kategori sangat baik dengan nilai diatas 82 . Membebaskan anak untuk memilih tempat perenungan dalam menulis cerpen dengan dipadukan model sinektik membantu siswa mengoptimalkan kreativitas dan idenya. Dibandingkan dengan rata-rata skor kemampuan menulis cerpen di siklus 1 mengalami kenaikan 7,99, sedangkan jika dibandingkan dengan pra skilus/sebelum tindakan mengalami kenaikan 17,35. Perbandingan skor rata-rata kemampuan menulis cerpen mulai pra tindakan sampai dengan siklus 2 seperti pada gambar 2 .

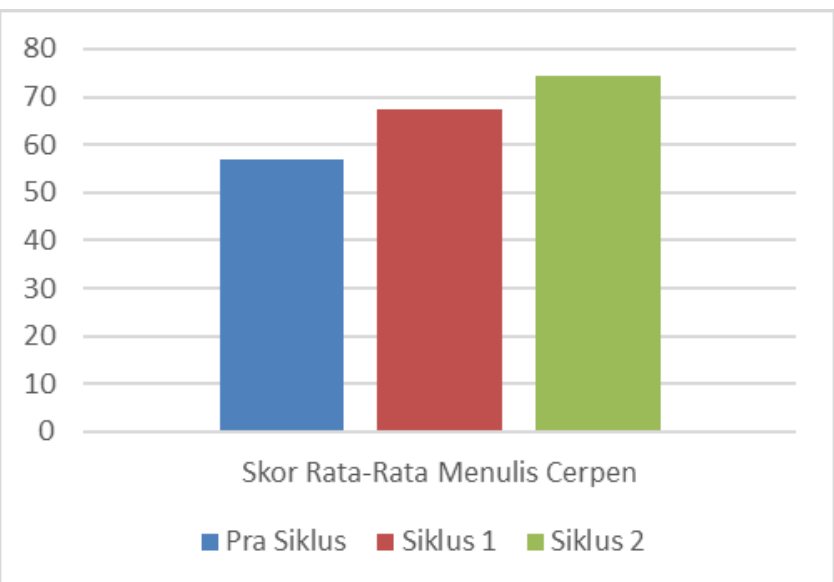

Gambar 2. Perbadingan Skor Rata Kemampuan Menulis Cerpen

Menulis masuk dalam kategori atau ranah kemampuan keterampilan (Sayekti, 2019). Pembelajaran menulis cerpen di sekolah merupakan pembelajaran yang menuntuk peserta didik mengasah kemampuan berpikir kreatif (Mubaroq \& Subyantoro, 2017). Pada siklus 2 menggabungkan model sinektis dengan pembelajaran diluar kelas bertujuan untuk membangun berpikir kreatif. Melatihkan siswa untuk menulis mendidik siswa untuk mengasah keterampilan menulis, karena memiliki kemampuan menulis yang baik dapat menjadikan siswa menjadi pribadi yang terpelajar (Sholeh \& Afriani, 2016). Siswa membutuhkan lebih banyak waktu untuk berlatih dalam menulis, siswa lebih membutuhkan waktu lebih banyak untuk membaca literature supaya kelak dapat menjadi penulis yang baik. Dalam pembelajaran keterampilan menulis siswa hendaknya mendapatkan kesempatan lebih banyak untuk praktek langsung dibandingkan dengan mendengarkan penjelasan guru terkait dengan teori tentang menulis.

\section{Kesimpulan}

Penerapan model sineksis dapat meningkatkan keterampilan menulis cerpen bagi siswa SMA. Rata-rata hasil keterampilan menulis siswa pasca mendapatkan treatmen pembelajaran Bahasa Indonesia dengan model sinektis sebesar 74,24 masuk kategori baik. Hasil penelitian menunjukkan 10\% siswa mampu mendapatkan kategori sangat baik untuk skor kemampuan menulis cerpen. 


\section{Ucapan Terimakasih}

Terimakasih disampaikan kepada kepala sekolah SMAN 1 Geger atas kesempatan dan waktu yang diberikan serta bimbingan dan arahan sehingga kami dapat menyelesaikan PTK dan penulisan artikel ilmiah dengan baik dan tepat waktu.

\section{Daftar Pustaka}

Amintaningsih, A. (2011). Peningkatan Keterampilan Menulis Cerpen Berbasis KUIK (Kisah, Unsur Intrinsik, Dan Khayalan) Melalui Model Sinektik Di Kelas X Sma Negeri 1 Pemalang. Lingua Didaktika, 2(2), 75-85. https://doi.org/https://doi.org/10.24036/ld.v4i2.1258

Hilal, I. N. (2013). Keefektifan Pembelajaran Menulis Cerpen dengan Menggunakan Model Problem Based Instruction (PBI) dan Model Sinektik pada Siswa Sma. Universitas Negeri Semarang.

Joyce, B., \& Weil, M. (1986). Models of Teaching. Prentice-Hall,Inc.

Kadarusman, G., \& Cahyono, B. E. H. (2018). Penggunaan Media Pembelajaran Pohon Ajaib dengan Model Pembelajaran Make A Match untuk Meningkatkan Penguasaan Kosa Kata Bahasa Indonesia Siswa Tunarungu Kelas II SDLB Dharma Wanita Jiwan Kabupaten Madiun. Linguista: Jurnal Ilmiah Bahasa, Sastra, Dan Pembelajarannya, 2(1), 61. https://doi.org/10.25273/linguista.v2i1.2756

Kemmis, S., \& McTaggart, R. (1988). The Action research planner (3rd ed.). Deakin University.

Kusrianti, A., \& Suharto, V. T. (2019). Penerapan Model Pembelajaran Problem Based Learning dengan Multimedia untuk Meningkatkan Kemampuan Menulis Puisi Siswa. Linguista: Jurnal Ilmiah Bahasa, Sastra, Dan Pembelajarannya, $3(2)$,

145-152. https://doi.org/10.25273/LINGUISTA.V3I2.5736

Latief, M. A. (2009). Classroom Action Research In Language Learning. http://sastra.um.ac.id/wp-

content/uploads/2009/11/Assumption_hypothesis.pdf

Mubaroq, A. K., \& Subyantoro, S. (2017). Keefektifan Pembelajaran Menulis Cerpen dengan Model Sinektik dan Model Kreatif-Produktif pada Peserta Didik SMA Berdasarkan Tipe Pemerolehan Informasi. In Seloka: Jurnal Pendidikan Bahasa dan Sastra Indonesia (Vol. 6, Issue 1).

Rostika, D. (2016). Model Sinektik Dalam Pengajaran Pengukuran Waktu Untuk Meningkatkan Kreativitas Siswa Sekolah Dasar. EduHumaniora / Jurnal Pendidikan Dasar Kampus Cibiru, 3(1). https://doi.org/10.17509/eh.v3i1.2786

Saragih, D. K. (2016). Peningkatan Keterampilan Menulis Novel Mahasiswa Jurusan Sastra Indonesia Dengan Model Sinektiks Budaya Komunikasi Indonesia. Prosiding Seminar Nasional UU ITE VS Budaya Komunikasi Di Indonesia, 1. 
Sayekti, S. (2019). Peningkatan Kemampuan Menulis Tegak Bersambung dengan Menggunakan Pembelajaran Model Jigsaw melalui Buku Tulis Halus pada Siswa Kelas II SDN 02 Mojorejo Kota Madiun. Linguista: Jurnal IImiah Bahasa, Sastra, Dan Pembelajarannya, 3(2), 91-104.

Setyaningsih, N. H. (2010). Peningkatan Keterampilan Menulis Cerpen Mahasiswa Jurusan Bahasa Dan Sastra Indonesia Dengan Model Sinektiks Yang Dikembangkan. Lingua, 6(2).

Sholeh, K., \& Afriani, S. (2016). Teknik Mind Mapping Sebagai Upaya Untuk Meningkatkan Keterampilan Menulis Cerpen Pada Siswa Sma. Jurnal Pendidikan Surya Edukasi (JPSE), 2(2), 27-45.

Wahyuni, E. (2015). Meningkatkan Keterampilan Menulis Cerpen Melalui Iklan Televisi Pada siswa Kelas IX A SMP Negeri 3 Balikpapan. Lingua, 12(2), 233-242. 